\title{
Anteseden dan Konsekuen Realisasi Belanja Modal Pada Provinsi di Indonesia
}

Arifahtun Zohrah ${ }^{1}$, Suyanto ${ }^{2}$

${ }^{1}$ Universitas Pancasila, Jl. Srengseng Sawah, Jagakarsa, Jakarta Selatan, 12640

${ }^{2}$ Sekolah Tinggi Ilmu Eonomi IPWI Jakarta, Jl. Letda Natsir No. 7, Cikeas Nagrek, Bogor, Jawa Barat

\section{INFO ARTIKEL}

JEL Classsification:

Keywords:

original local income

(PAD), balance

fund, government

expenditure realization,

economic growth.

\section{A B S TR A C T}

The purpose of this research is to examine the antecendent of Government Expenditure Realization, whether there is influence of Original Local Income (PAD) and Balance Fund against Government Expenditure Realization, and to examine the consequence of Government Expenditure Realization, whether there is influence of Government Expenditure Realization against Economic Growth. The population of this research is 33 Provinces of Indonesia, and used secondary data of Government Budgets-realization of Indonesia Provinces from 2009 until 2013. This research used multiple regression in antecendent of Government Expenditure Realization testing and simple regression in consequence of Government Expenditure Realization testing. The hypothesis testing consist of coefficient of determination test, F test, and t test. The research revealed that in antecendent of Government Expenditure Realization testing, partially Original Local Income (PAD) variable and Balance Fund variable influence Government Expenditure Realization, and in Consecuent Government Expenditure Realization testing, partially Government Expenditure Realization influence Economic Growth.

\section{A B S T R A K}

Tujuan dari penelitian ini adalah untuk menguji Anteseden Realisasi Belanja Modal yaitu pengaruh Pendapatan Asli Daerah dan Dana Perimbangan terhadap Realisasi Belanja Modal, serta untuk menguji Konsekuen Realisasi Belanja Modal yaitu pengaruh Realisasi Belanja Modal terhadap Pertumbuhan Ekonomi. Populasi dalam penelitian ini adalah Provinsi di Indonesia, dan menggunakan data sekunder yang berupa Laporan Realisasi Anggaran (LRA) tahun 2009 sampai dengan tahun 2013. Penelitian ini menggunakan regresi berganda dalam pengujian Anteseden Realisai Belanja Modal dan regresi sederhana untuk pengujian Konsekuen Realisasi Belanja Modal. Uji hipotesis terdiri dari uji koefisien determinasi, uji F, dan uji t. Hasil penelitian menunjukkan bahwa dalam pengujian Anteseden Realisasi Belanja Modal, secara parsial Pendapatan Asli Daerah dan Dana Perimbangan berpengaruh terhadap Realisasi Belanja Modal, dan dalam Pengujian kosekuen, Realisasi Belanja Modal secara parsial berpengaruh terhadap Pertumbuhan Ekonomi.

*Email Korespondensi: ${ }^{1}$ arifahtunzohrah@yahoo.co.id 


\section{Pendahuluan}

Kebijakan otonomi daerah merupakan kewenangan yang diberikan kepada pemerintah daerah untuk mengatur dan mengurus tiap-tiap daerah. Hal ini mendorong pemerintah daerah untuk mempercepat terwujudnya kesejahteraan masyarakat melalui peningkatan pelayanan, pemberdayaan dan peran serta masyarakat. Tetapi, kemampuan daerah yang satu dengan daerah yang lainnya dalam mengelola potensi lokalnya dan ketersediaan sarana prasarana serta sumber daya sangat berbeda. Perbedaan ini dapat menyebabkan pertumbuhan ekonomi yang beragam antara satu daerah dengan daerah lainnya (Nugroho, 2010). Oleh karena itu diperlukan suatu perencanaan keuangan atas anggaran daerah dalam melaksanakan fungsi meningkatkan pelayanan publik (public service) dan memajukan perekonomian daerah. PP Nomor 58 Tahun 2005 menyatakan bahwa APBD merupakan rencana keuangan tahunan Pemerintah Daerah yang dibahas dan disetujui bersama oleh Pemerintah Daerah dan DPRD, dan ditetapkan dengan Peraturan Daerah.

Dalam penyelenggaraan desentralisasi fiskal, Pemerintah Daerah harus mampu memberikan fasilitas pelayanan publik yang lebih baik untuk masyarakat lokal. Dengan adanya desentralisasi fiskal, daerah mempunyai kewenangan yang lebih besar untuk mengoptimalkan PAD-nya sehingga seharusnya porsi PAD sebagai komponen penerimaan daerah juga meningkat Penthury (2011). Namun tidak berarti jika kemandirian keuangan daerah tinggi maka daerah sudah tidak perlu lagi mendapatkan dana perimbangan. Dana perimbangan masih tetap diperlukan untuk mempercepat pembangunan daerah (Mahmudi, 2010). Selain itu, realita menunjukkan bahwa tidak seluruhnya daerah mampu menghilangkan ketergantungan terhadap pemerintah pusat, hal ini disebabkan karena tingkat pendapatan tiap daerah berbeda-beda, sehingga dana perimbangan ini dapat membantu daerah dalam mengatasi ketimpangan fiskal.
Pemerintah daerah mengalokasikan anggaran daerah salah satunya dalam bentuk belanja modal untuk menambah aset tetap yang sesuai dengan kebutuhan akan sarana dan prasarana, serta untuk membangun sektor-sektor yang produktif di daerah. Dengan tingginya tingkat investasi modal, diharapkan dapat meningkatkan produktivitas yang berimplikasi pada peningkatan pendapatan per kapita penduduk yang pada akhirnya dapat mendorong pertumbuhan ekonomi.

Penelitian tentang pengaruh PAD terhadap Realisasi Belanja Modal ditemukan pada beberapa penelitian. Darwanto dan Yustikasari (2007), Jaya dan Dwirandra (2014), Arwati dan Hadiati (2013), serta Sholikhah dan Wahyudin (2014) membuktikan bahwa PAD berpengaruh positif terhadap Realisasi Belanja Modal. Begitu pula Lambut dan Budiarso (2013), Lantang, dkk (2014), serta Wenas, dkk (2014) membuktikan bahwa PAD berpengaruh terhadap Belanja Daerah. Nugraeni (2011) menyimpulkan bahwa PAD berpengaruh terhadap prediksi Belanja Daerah. Laksono dan Subowo (2014) menemukan bahwa Pajak Daerah berpengaruh positif terhadap Belanja Daerah. Namun penelitian Oktora dan Pontoh (2013) menyimpulkan bahwa PAD dan Realisasi Belanja Modal tidak berhubungan erat, Wandira (2013) menemukan bahwa dengan arah negatif PAD tidak berpengaruh signifikan terhadap Realisasi Belanja Modal. Demikian juga dengan Laksono dan Subowo (2014) yang menyimpulkan bahwa Retribusi Daerah tidak berpengaruh terhadap Belanja Daerah.

Penelitian tentang pengaruh Dana Perimbangan terhadap Realisasi Belanja Modal ditemukan pada beberapa penelitian, diantaranya penelitian Darwanto dan Yustikasari (2007) serta Harianto dan Adi (2007) yang menyimpulkan bahwa DAU berpengaruh positif terhadap Realisasi Belanja Modal, Sholikhah dan Wahyudin (2014) menemukan bahwa DBH berpengaruh signifikan terhadap Realisasi Belanja Modal, Wandira (2013) menemukan 
bahwa DAK dan DBH berpengaruh signifikan terhadap Realisasi Belanja Modal, dan DAU dengan arah negatif berpengaruh terhadap Realisasi Belanja Modal. Oktora dan Pontoh (2013) menyimpulkan bahwa DAU berhubungan sangat erat dengan Realisasi Belanja Modal dan DAK berhubungan erat dengan Realisasi Belanja Modal. Lantang, dkk (2014) membuktikan bahwa DAU berpengaruh terhadap Belanja Daerah, Wenas,dkk (2014), serta Lambut dan Budiarso (2013) menemukan DAU berpengaruh positif dan signifikan terhadap Belanja Daerah, Nugraeni (2011) menyimpulkan bahwa DAU dan DAK merupakan faktor yang signifikan untuk prediksi Anggaran Belanja Daerah, Laksono dan Subowo (2014) membuktikan bahwa DAU dan DAK berpengaruh positif terhadap Belanja Daerah, Ulum (2005) membuktikan bahwa Dana Perimbangan berpengaruh signifikan terhadap Belanja Daerah. Namun penelitian Arwati dan Hadiati (2013) menemukan bahwa DAU tidak berpengaruh signifikan terhadap Pengalokasian Anggaran Realisasi Belanja Modal, serta Sholikhah dan Wahyudin (2014) yang membuktikan bahwa DAU mempunyai arah negatif dan tidak berpengaruh secara signifikan terhadap Realisasi Belanja Modal.

Penelitian tentang pengaruh Realisasi Belanja Modal terhadap Pertumbuhan Ekonomi ditemukan pada beberapa penelitian, diantaranya Penelitian Lapian, dkk (2014) menyimpulkan bahwa Belanja Daerah berpengaruh positif dan signifikan terhadap Pertumbuhan Ekonomi. Adi (2006) menyimpulkan bahwa Belanja Pembangunan memberikan dampak positif dan signifikan terhadap Pertumbuhan Ekonomi. Namun penelitian Anasmen (2009) menemukan bahwa Realisasi Belanja Modal Pemerintah tidak signifikan mempengaruhi pertumbuhan Produk Domestik Regional Bruto, serta Gunantara dan Dwirandra (2014) menemukan bahwa Realisasi Belanja Modal berpengaruh negatif dan siginifikan terhadap Pertumbuhan Ekonomi.

Berdasarkan studi empiris sebelumnya, maka penelitian ini dilakukan bertujuan untuk menganalisis pengaruh Pendapatan Asli Daerah dan Dana Perimbangan terhadap Realisasi Belanja Modal, dan menganalisis pengaruh Realisasi Belanja Modal terhadap Pertumbuhan Ekonomi.

\section{Telaah Teori dan Pengembangan Hipotesis}

Menurut Mardiasmo (2009: 132), Pendapatan Asli Daerah adalah penerimaan yang diperoleh dari sektor pajak daerah, retribusi daerah hasil perusahaan milik daerah/ hasil pengelolaan kekayaan daerah yang dipisahkan, dan Lain-lain Pendapatan Asli Daerah Yang Sah.

PP Nomor 55 Tahun 2005 menyatakan bahwa Dana Perimbangan adalah dana yang bersumber dari pendapatan APBN yang dialokasikan kepada daerah untuk mendanai kebutuhan daerah dalam rangka pelaksanaan Desentralisasi. Dana Perimbangan terdiri atas Dana Bagi Hasil, Dana Alokasi Umum, dan Dana Alokasi Khusus.

Menurut PP Nomor 71 Tahun 2010, belanja modal adalah pengeluaran anggaran untuk perolehan aset tetap dan aset lainnya yang memberi manfaat lebih dari satu periode akuntansi. Belanja modal meliputi antara lain belanja modal untuk perolehan tanah, gedung dan bangunan, peralatan, dan aset tak berwujud.

Case \& Fair (2007) menjelaskan bahwa Pertumbuhan Ekonomi adalah peningkatan total output dalam suatu perekonomian. Untuk mengukur pertumbuhan ekonomi para ekonom menggunakan data Produk Domestik Regional Bruto (Mankiw, 2007:182). Menurut BPS (2008), Produk Domestik Regional Bruto (PDRB) adalah jumlah nilai produk barang dan jasa akhir yang dihasilkan oleh berbagai unit produksi dalam suatu wilayah/region pada suatu jangka waktu tertentu, biasanya setahun.

PDRB terdiri dari PDRB Rill dan PDRB Nominal. PDRB Riil nilainya diukur atas dasar harga konstan, sedangkan PDRB Nominal adalah PDRB yang dinilai atas dasar harga berlaku (Abrar, 2010). PDRB Nominal atau 
PDRB atas dasar harga berlaku menggambarkan nilai tambah barang dan jasa yang dihitung dengan menggunakan harga pada setiap tahun. Sedangkan PDRB Riil atau PDRB atas dasar harga konstan menunjukkan nilai tambah barang dan jasa yang dihitung menggunakan harga pada satu tahun tertentu sebagai tahun dasar penghitungannya (Supatman, 2010). Karena kemampuan masyarakat untuk memenuhi kebutuhan ekonomi sangat bergantung pada jumlah barang dan jasa yang diproduksi, maka PDRB Riil memberikan ukuran kemakmuran ekonomi yang lebih baik daripada PDRB Nominal (Mankiw, 2007:23), Sehingga indikator PDRB yang digunakan untuk menghitung pertumbuhan ekonomi adalah nilai PDRB atas dasar harga konstan tahun 2000.

\section{Pengaruh Pendapatan Asli Daerah terhadap Realisasi Belanja Modal}

Peningkatan PAD yang dianggap sebagai modal, secara akumulasi akan lebih banyak menimbulkan eksternalitas yang bersifat positif dan akan mempercepat pertumbuhan ekonomi (Pujiati, 2008). Di dalam UU No.33/2004 dijelaskan bahwa PAD bertujuan memberikan kewenangan kepada pemerintah daerah untuk mendanai pelaksanaan otonomi daerah sesuai dengan potensi daerah sebagai perwujudan desentralisasi.

Penelitian terkait pengaruh PAD terhadap realisasi belanja modal telah diteliti oleh beberapa peneliti sebelumnya diantaranya Darwanto dan Yustikasari (2007) yang melakukan penelitian di daerah se Jawa-Bali, Jaya dan Dwirandra (2014) dengan penelitiannya pada kabupaten/kota di provinsi Bali, Arwati dan Hadiati (2013) yang meneliti di Pemerintah Daerah Kabupaten/ Kota di Provinsi Jawa Barat, serta Sholikhah dan Wahyudin (2014) yang melakukan penelitian pada kab/kota di Jawa membuktikan bahwa PAD berpengaruh positif terhadap Realisasi Belanja Modal. Begitu pula Lambut dan Budiarso (2013) yang melakukan penelitian di pemerintah provinsi Sulawesi
Utara, Lantang, dkk (2014) yang meneliti di kota Manado, serta Wenas, dkk (2014) yang meneliti pada pemerintah kota Manado membuktikan bahwa PAD berpengaruh terhadap Belanja Daerah. Nugraeni (2011) dengan penelitiannya di kabupaten/kota di Indonesia menyimpulkan bahwa PAD berpengaruh terhadap prediksi Belanja Daerah. Laksono dan Subowo (2014) dengan penelitiannya pada Kabupaten/ Kota di Jawa Tengah dan DIY menemukan bahwa Pajak Daerah berpengaruh positif terhadap Belanja Daerah..Berdasarkan beberapa bukti empiris yang telah diuraikan diatas, maka hipotesis yang penelitian ini adalah :

H1: Terdapat pengaruh Pendapatan Asli Daerah terhadap Realisasi Belanja Modal.

\section{Pengaruh Dana Perimbangan terhadap Realisasi Belanja Modal \\ PP Nomor 55 tahun 2005 menegaskan} adanya pembagian dana perimbangan yang adil, demokratis dan merata terhadap daerah-daerah di Indonesia demi menopang kinerja pemerintah daerah dalam menyukseskan pembangun daerah. Ndadari dan Adi (2008) menyatakan bahwa DAK bisa disamakan dengan belanja pembangunan karena digunakan untuk mendanai peningkatan kualitas pelayanan publik berupa pembangunan sarana dan prasarana publik.

Hasil penelitian terkait terdpat pengaruh dana perimbangan terhadap realisasi belanja modal telah dilakukan oleh Hasil penelitian ini konsisten dengan hasil penelitian terdahulu yang dilakukan oleh Darwanto dan Yustikasari (2007) dengan penelitiannya pada pemerintah daerah se Jawa-Bali, serta Harianto dan Adi (2007) yang melakukan penelitian di kabupaten dan kota se Jawa-Bali menyimpulkan bahwa DAU berpengaruh positif terhadap Realisasi Belanja Modal, Sholikhah dan Wahyudin (2014) dengan penelitiannya pada kab/kota di Jawa menemukan bahwa DBH berpengaruh signifikan terhadap Realisasi Belanja Modal, Wandira (2013) yang meneliti di Pemerintah Provinsi se-Indonesia menemukan bahwa DAK dan 
DBH berpengaruh signifikan terhadap Realisasi Belanja Modal, dan DAU dengan arah negatif berpengaruh terhadap Realisasi Belanja Modal. Oktora dan Pontoh (2013) dengan penelitiannya di kabupaten Tolitoli Provinsi Sulawesi Tengah menyimpulkan bahwa DAU berhubungan sangat erat dengan Realisasi Belanja Modal dan DAK berhubungan erat dengan Realisasi Belanja Modal. Lantang, dkk (2014) yang melakukan penelitian pada kota Manado membuktikan bahwa DAU berpengaruh terhadap Belanja Daerah, Wenas,dkk (2014) yang meneliti di kota Manado, serta Lambut dan Budiarso (2013) yang melakukan penelitian di pemerintah provinsi Sulawesi Utara menemukan DAU berpengaruh positif dan signifikan terhadap Belanja Daerah, Nugraeni (2011) dengan penelitiannya pada kabupaten/kota di Indonesia menyimpulkan bahwa DAU dan DAK merupakan faktor yang signifikan untuk prediksi Anggaran Belanja Daerah, Laksono dan Subowo (2014) yang meneliti pada Kabupaten/Kota di Jawa Tengah dan DIY membuktikan bahwa DAU dan DAK berpengaruh positif terhadap Belanja Daerah, Ulum (2005) dengan penelitian yang dilakukan pada Provinsi di Indonesia membuktikan bahwa Dana Perimbangan berpengaruh signifikan terhadap Belanja Daerah.

Berdasarkan beberapa bukti empiris yang telah diuraikan diatas, maka hipotesis yang penelitian ini adalah :

H2: Terdapat pengaruh Dana Perimbangan terhadap Realisai Belanja Modal.

\section{Pengaruh Realisasi Belanja Modal terhadap Pertumbuhan Ekonomi}

Pada prinsipnya kebijakan belanja bertujuan pada pencapaian tiga hal : Pertumbuhan Ekonomi, Pemerataan Ekonomi, dan Stabilitas Ekonomi (Mahmudi,2010:79). Pengeluaran pemerintah merupakan bagian dari kebijakan fiskal pemerintah yang bertujuan untuk memacu pertumbuhan ekonomi (Tambunan, 2011). Infrastruktur merupakan kunci dari Pertumbuhan Ekonomi, dengan menyiapkan infrastruktur yang baik, maka akan meningkatkan produktivitas (Modebe et al, 2012).Hasil penelitian terkait terdapat pengaruh realisasi belanja modal terhadap pertumbuhan ekonomi telah dilakukan oleh Hasil penelitian ini sejalan dengan Lapian, dkk (2014) yang meneliti pada kota Manado menyimpulkan bahwa Belanja Daerah berpengaruh positif dan signifikan terhadap Pertumbuhan Ekonomi. Adi (2006) dengan penelitiannya pada kabupaten dan kota se Jawa-Bali menyimpulkan bahwa Belanja Pembangunan memberikan dampak positif dan signifikan terhadap Pertumbuhan Ekonomi. Berdasarkan beberapa bukti empiris yang telah diuraikan diatas, maka hipotesis yang penelitian ini adalah :

H3: Terdapat pengaruh Realisasi Belanja Modal terhadap Pertumbuhan Ekonomi.

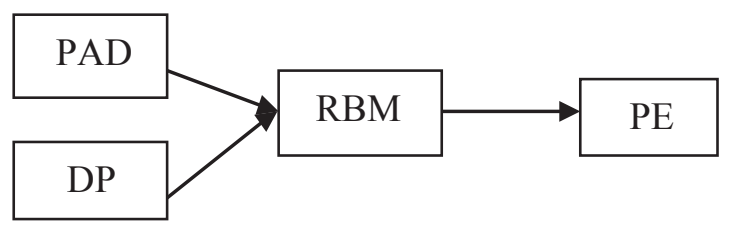

Gambar 1. Model Penelitian

\section{Metode}

Penelitian ini mencoba untuk mengumpulkan dan menganalisis data untuk sampai pada kesimpulan tentang besarnya pengaruh PAD dan Dana Perimbangan terhadap Realisasi Belanja Modal dan besarnya pengaruh Realisai Belanja Modal terhadap Pertumbuhan Ekonomi. Anteseden adalah hal yang mempengaruhi Realisasi Belanja Modal, sedangkan Konsekuen adalah hal yang dipengaruhi Realisasi Belanja Modal. Anteseden Realisasi Belanja Modal dalam penelitian ini yaitu Pendapatan Asli Daerah (PAD) dan Dana Perimbangan (DP), sedangkan Konsekuen Realisasi Belanja Modal dalam penelitian ini yaitu Pertumbuhan Ekonomi, sehingga variabel Pendapatan Asli Daerah dan Dana Perimbangan merupakan variabel bebas (Independent Variable) bagi 
Realisasi Belanja Modal (RBM), dan Realisasi Belanja Modal (RBM) menjadi variabel bebas (Independent Variable) bagi Pertumbuhan Ekonomi (PE). Oleh karena itu pada penelitian ini Realisasi Belanja Modal (RBM) bertindak sebagai variabel bebas (Independent Variable) dan variabel terikat (Dependent Variabel), namun bukan menjadi variabel intervening.

Populasi yang menjadi objek dalam penelitian ini adalah, 33 Provinsi di Indonesia, dengan periode penelitian selama 5 tahun berturut-turut mulai tahun 2009 sampai dengan 2013. Sejak Tahun 2012 Provinsi di Indonesia jumlahnya menjadi 34 , hal ini ditandai dengan terdapatnya Provinsi baru di Pulau Kalimantan yaitu Provinsi Kalimantan Utara yang resmi disahkan menjadi Provinsi dalam rapat paripurna DPR pada tanggal 25 Oktober 2012 berdasarkan Undang-undang Nomor 20 Tahun 2012. Namun nama dan data provinsi tersebut belum tercantum pada www.djpk.depkeu.go.id dan www.bps.go.id yang menjadi sumber data dalam penelitian ini sehingga data yang digunakan dalam penelitian ini hanya 33 Provinsi.

Penelitian ini menggunakan data sekunder yang berupa Laporan Realisasi APBD yang terdiri dari Pendapatan Asli Daerah (PAD), Dana Perimbangan, dan Belanja Modal pada Provinsi di seluruh Indonesia yang diperoleh dari situs Dirjen Perimbangan Keuangan Pemerintah Daerah melalui www.djpk.depkeu.go.id, dan Data Pertumbuhan Ekonomi (PDRB) Atas Dasar Harga Konstan 2000 Menurut Provinsi pada masing-masing Provinsi di seluruh Indonesia yang diperoleh dari situs Badan Pusat Statistik melalui www.bps.go.id.

Penentuan sampel dilakukan dengan cara sampling purposive (purposive sampling), sampling purposive adalah teknik penentuan sampling dengan pertimbangan tertentu (Sugiyono, 2008). Sampel yang digunakan dalam penelitian ini adalah Provinsi di seluruh indonesia dengan pertimbangan diantaranya: (1) Provinsi di seluruh Indonesia yang mempublikasikan Laporan Realisasi Anggarannya selama periode
2009-2013. (2) Provinsi yang Laporan Realisasi Aggarannya telah di audit BPK. (3) Provinsi di seluruh indonesia yang memiliki laporan lengkap di BPS tentang Pertumbuhan Ekonomi.

Berdasarkan kriteria yang telah disebutkan di atas, dari 33 Provinsi di Indonesia, hanya sebanyak 32 provinsi yang memenuhi kriteria untuk dijadikan sampel penelitian.

Metode analisa data yang digunakan dalam penelitian ini adalah metode analisa data multivariate yang merupakan metode statistik deskriptif dan inferensial yang digunakan untuk menganalisa data lebih dari dua variabel penelitian, dengan bantuan program Statistical Package for Social Science (SPSS) 21.

Pendapatan Asli Daerah (PAD) yang dimaksud dalam penelitian ini adalah mengukur seberapa besar derajat kontribusi PAD terhadap total penerimaan daerah. Semakin tinggi kontribusi PAD maka semakin tinggi kemampuan pemerintah daerah dalam penyelenggaraan desentralisasi. Pengukuran variabel PAD dengan menggunakan instrument yang dikembangkan oleh Mahmudi, (2010). Instrumen diukur dengan skala Rasio dengan rumus Derajat Desentralisasi $=$ Pendapatan Asli Daerah/Total Pendapatan Daerah $\times 100 \%$

Dana Perimbangan (DP) yang dimaksud dalam penelitian ini adalah mengukur seberapa besar ketergantungan keuangan daerah. Semakin tinggi Pendapatan Transfer, maka semakin besar tingkat ketergantungan pemerintah daerah terhadap pemerintah pusat dan / atau pemerintah provinsi. Pengukuran variabel DP dengan menggunakan instrument yang dikembangkan oleh Mahmudi, (2010). Instrumen diukur dengan skala Rasio dengan rumus Rasio Ketergantungan Keuangan Daerah $=$ Pendapatan Transfer/Total Pendapatan Daerah $\times 100 \%$.

Realisasi Belanja Modal (RBM) dalam penelitian ini adalah mengukur seberapa besar porsi belanja daerah yang direalisasikan melalui belanja modal. Belanja modal ini akan mempengaruhi neraca pemerintah daerah, yaitu menambah aset daerah. Pengukuran 
variabel RBM dengan menggunakan instrument yang dikembangkan oleh Mahmudi, (2010). Instrumen diukur dengan skala Rasio dengan rumus Analisis Belanja Modal = Realisasi Belanja Modal/Total Belanja Daerah.

Pertumbuhan Ekonomi (PE) di dalam penelitian adalah mengukur tingkat pertumbuhan ekonomi yang berbeda dari tahun sebelumnya, apakah mengalami penurunan ataupun peningkatan. Pengukuran variabel PE dengan menggunakan instrument yang dikembangkan oleh Kuncoro, (2014). Instrumen diukur dengan skala Rasio dengan rumus Pertumbuhan Ekonomi $=($ PDRBt-PDRBt-1) $/$ PDRBt $-1 x$ $100 \%$.

Sebelum melakukan pengujian hipotesis dengan menggunakan analisis regresi, diperlukan pengujian asumsi klasik terlebih dahulu untuk melihat apakah model yang telah dibuat tersebut tidak melanggar asumsi-asumsi klasik yang berlaku di dalam suatu persamaan regresi linier. Uji tersebut yaitu:

Uji Normalitas bertujuan untuk mengetahui distribusi data dalam variabel yang digunakan dalam penelitian. Data yang baik dan layak digunakan dalam penelitian adalah data yang memiliki distribusi normal (Nugroho, 2005:18). Untuk menguji apakah distribusi normal atau tidak dapat dilihat melalui normal probability plot dengan membandingkan distribusi kumulatif dan distribusi normal. Data normal akan membentuk satu garis lurus diagonal, dan ploting data akan dibandingkan dengan garis diagonal. Jika distribusi data adalah normal, maka garis yang menggambarkan data sesungguhnya akan mengikuti garis diagonalnya (Ghozali, 2006:110).

Uji Multikolinieritas ini diperlukan untuk mengetahui apakah ada tidaknya variabel independen yang memiliki kemiripan dengan variabel independen lain dalam satu model (Nugroho, 2005:58). Deteksi pada multikolinieritas juga bertujuan untuk menghindari bias dalam proses pengambilan keputusan terkait pengaruh pada uji parsial masing-masing variabel independen terhadap variabel dependen. Deteksi multikolinieritas pada suatu model dapat dilihat jika nilai Variance Inflation Factor (VIF) tidak lebih dari 10 dan nilai Tolerance tidak kurang dari 0,1 , maka model tersebut terbebas dari multikolinieritas. VIF $=1 /$ Tolerance, Jika VIF $=10$ maka Tolerance $=1 / 10$ $=0,1$ (Ghozali, 2006:92).

Uji Heteroskedastisitas bertujuan untuk menguji apakah model regresi terjadi ketidaksamaan variance dari residual satu pengamatan ke pengamatan lain (Ghozali, 2006:105). Model regresi yang baik adalah model regresi yang memiliki kesamaan variance residual suatu periode pengamatan dengan pengamatan yang lain (homokesdastisitas). Cara memprediksi ada tidaknya heteroskedastisitas pada suatu model dapat dilihat dari pola gambar scatter plot model tersebut (Ghozali, 2006:105).

Uji Autokorelasi bertujuan untuk mengetahui apakah model regresi linier ada korelasi kesalahan pengganggu pada periode $t$ dan dengan kesalahan pengganggu pada periode t-1 (periode sebelumnya) (Ghozali,2006:95). Jika terjadi korelasi, maka dinamakan terdapat problem korelasi. autokorelasi muncul karena observasi yang berurutan sepanjang waktu berkaitan satu sama lainnya. Pengujian Autokorelasi dilakukan dengan menggunakan uji Durbin Watson (Durbin Watson Test).

Pengujian Hipotesis dilakukan dengan menggunakan model regresi berganda (multiple regression) dan regresi sederhana (simple regression) dengan persamaan sebagai berikut:

Persamaan 1 : $\mathrm{RBM}=\mathrm{a}+\mathrm{b} 1 \mathrm{PAD}+\mathrm{b} 2 \mathrm{DP}+\mathrm{e}$ Persamaan 2: $P E=a+b R B M+e$ Dimana :

$\mathrm{a}=$ Konstanta

PAD $=$ Pendapatan Asli Daerah

$\mathrm{DP}=$ Dana Perimbangan

$\mathrm{RBM}=$ Realisasi Belanja Modal

$\mathrm{PE}=$ Pertumbuhan Ekonomi

e $\quad=$ Error

Pengujian determinasi $\left(\mathrm{R}^{2}\right)$ pada intinya mengukur seberapa jauh kemampuan model 
dalam menerangkan variasi variabel dependen. Nilai koefisien determinasi adalah antara nol dan satu. Nilai $\mathrm{R}^{2}$ yang kecil berarti brarti kemampuan variabel-variabel independen dalam menjelaskan variabel dependen amat terbatas. Nilai yang mendekati satu berarti variabelvariabel independen memberikan hampir semua informasi yang dibutuhkan untuk memprediksi variasi variabel dependen (Ghozali, 2006:83).

Untuk menguji apakah hipotesis yang diajukan diterima atau ditolak, maka dilakukan pengujian terhadap variabel-variabel penelitian dengan cara menguji secara simultan melalui signifikansi simultan (Uji statistik F), yang bermaksud untuk dapat menjelaskan apakah semua variabel independen atau bebas yang dimasukkan dalam model mempunyai pengaruh secara bersama-sama terhadap variabel dependen/terikat Ghozali, 2006:84). Nilai F table dengan menggunakan signifikasi $\alpha$ dan derajat kebebasan (df) tertentu. Dengan membandingkan antara nilai $\mathrm{F}$ hitung dengan $\mathrm{F}$ table jika F hitung > F table, maka H0 ditolak dan $\mathrm{H} 1$ diterima.

Pengujian masing-masing variabel secara parsial dilakukan uji signifikasi parameter individual (uji $\mathrm{t}$ statistik) yang memiliki tujuan untuk mengetahui seberapa jauh pengaruh satu variabel independen secara individual dalam menerangkan variasi variabel dependen Ghozali (2006). Dengan membandingkan antara nilai $t$ hitung maka dapat ditentukan kriteria pengujian sebagai berikut :

1. Jika $\mathrm{t}$ hitung $<\mathrm{t}$ tabel, maka $\mathrm{H} 0$ diterima $\mathrm{Ha}$ ditolak.

2. Jika thitung $>\mathrm{t}$ tabel, maka $\mathrm{H} 0$ ditolak $\mathrm{Ha}$ diterima.

\section{Hasil Penelitian dan Pembahasan}

Uji normalitas statistik dapat dilihat dari uji Kolmogorov-smirnov. Berdasarkan hasil pengujian, maka diperoleh nilai KolmogorovSmirnov sebesar 0,72, dengan tingkat signifikansi pada 0,674 , sehingga dapat dilihat bahwa nilai signifikansi Kolmogorov-Smirnov lebih besar dari $5 \%(>0,05)$. Artinya residual terdistribusi secara normal atau dengan kata lain residual berdistribusi normal. Hasil uji multikolinieritas terlihat bahwa nolai TOL (Tolerance) variabel lebih besar dari 0,10, sedangkan nilai VIF (Variance Inflating Factor) lebih kecil dari 10. Dengan demikian dalam model ini tidak ada masalah multikolinearitas. Pengujian Heteroskedastisitas dalam penelitian ini menggunakan uji Glejser. Berdasarkan hasil uji Glejser, dapat dilihat bahwa tingkat probabilitas siginfikansi masing-masing variabel independen di atas tingkat kepercayaan $5 \%(>0,05)$. Jadi dapat disimpulkan bahwa model regresi tidak mengandung adanya Heteroskedastisitas. Salah satu cara yang dapat digunakan dalam pengujian Autokorelasi yaitu dengan uji Durbin-Watson (DW Test). Berdasarkan hasil analisis regresi diperoleh output nilai hitung Durbin Watson $(D W)$ sebesar 1.903. Besarnya $D W$-tabel yaitu $d u$ (batas dalam) dengan signifikasi $5 \%$, jumlah sampel (n) 96 dan jumlah variabel independen $2(\mathrm{k}=2)$ adalah 1.7103 , dan nilai $d l$ (batas luar) 1.6254. Nilai dari $4-d u=2,2897$, dan $4-d l$ $=23746$. Sehingga dapat disimpulkan bahwa $1.7103<1.903<2,2897$. Apabila dilihat dari angka DW sebesar 1.903 berada diantara $d u$ (1.7103) dan 4-du (2,2897), maka dapat dilihat bahwa tidak terdapat autokorelasi positif atau negative, sehingga dapat disimpulkan bahwa masing-masing variabel tidak terdapat autokorelasi. 
Tabel 1. Hasil Pengujian

\begin{tabular}{|c|c|c|c|c|c|c|c|c|}
\hline \multirow{2}{*}{ Ket. } & \multicolumn{4}{|c|}{ Anteseden Realisasi Belanja Modal } & \multicolumn{4}{|c|}{ Konsekuen Realisasi Belanja Modal } \\
\hline & B & Std. Error & t-hitung & Sig. & B & Std. Error & t-hitung & Sig. \\
\hline (PAD) & -.055 & .010 & -5.440 & .000 & & & & \\
\hline (DP) & .624 & .026 & 23.699 & .000 & & & & \\
\hline$(\mathrm{RBM})$ & & & & & 87.848 & 15.731 & 5.584 & .000 \\
\hline Constant & -98324.698 & 33099.080 & -2.971 & .004 & 21071898.22 & 14302171.23 & 1.473 & .144 \\
\hline$R$-Square & .901 & & & & .249 & & & \\
\hline $\begin{array}{l}\text { Adjusted } \\
R \text {-Square }\end{array}$ & .899 & & & & .241 & & & \\
\hline F-hitung & 425.016 & & & & 31.186 & & & \\
\hline Sig. F & .000 & & & & .000 & & & \\
\hline
\end{tabular}

Hasil uji parsial (uji t) pada anteseden realisasi belanja modal menunjukkan bahwa variabel Pendapatan Asli Daerah (PAD) memiliki t hitung sebesar -5,440 lebih kecil dari $\mathrm{t}$ tabel sebesar 1,661 dengan nilai signifikansi sebesar 0.000 atau lebih kecil dari $0.05(\alpha=$ $5 \%$ ), sehingga hipotesis alternatif (Ha) diterima dan menolak hipotesis nol (Ho) artinya bahwa "Pendapatan Asli Daerah berpengaruh terhadap Realisasi Belanja Modal", dan variabel Dana Perimbangan (DP) memiliki t hitung sebesar 23,699 lebih besar dari t tabel sebesar 1,660 dengan nilai signifikansi sebesar 0.000 atau lebih kecil dari $0.05(\alpha=5 \%)$, sehingga hipotesis alternatif (Ha) diterima dan menolak hipotesis nol (Ho) artinya bahwa "Dana Perimbangan berpengaruh terhadap Realisasi Belanja Modal".

Hasil uji parsial (uji t) pada konsekuen realisasi belanja modal menunjukkan bahwa Variabel Belanja Modal memiliki $t$ hitung sebesar 5,584 lebih besar dari t tabel sebesar 1,661 dengan nilai signifikansi sebesar 0.000 atau lebih kecil dari $0.05(\alpha=5 \%)$, sehingga hipotesis alternatif (Ha) diterima dan menolak hipotesis nol (Ho) artinya bahwa "Realisasi Belanja Modal berpengaruh terhadap Pertumbuhan Ekonomi”.

\section{Simpulan, Keterbatasan, dan Implikasi Hasil Penelitian}

Menurut hasil penelitian yang telah dilakukan, maka terdapat beberapa kesimpulan bahwa hasil penelitian dengan pengujian secara parsial (uji t) pada pengaruh Pendapatan Asli Daerah terhadap Realisasi Belanja Modal membuktikan bahwa Pendapatan Asli Daerah berpengaruh terhadap Realisasi Belanja Modal. Hal ini berarti besarnya komponen Pendapatan Asli Daerah yang terdiri dari Pajak Daerah, Retribusi Daerah, dan Lain-lain Pendapatan Asli Daerah Yang Sah yang diperoleh pemerintah provinsi berpengaruh pada dana yang dikeluarkan untuk realisasi belanja modal pada provinsi di Indonesia. Hasil pengujian secara parsial pada pengaruh Dana Perimbangan terhadap Realisasi Belanja Modal membuktikan bahwa Dana Perimbangan berpengaruh terhadap Realisasi Belanja Modal. Artinya semakin besar komponen Dana Perimbangan yang terdiri dari Dana Alokasi Umum, Dana Alokasi Khusus dan Dana Bagi Hasil, maka semakin besar dana yang dikelurakan untuk realisasi belanja modal pada pemerintah provinsi di Indonesia. Pengujian secara parsial pada pengaruh Realisasi Belanja Modal terhadap Pertumbuhan Ekonomi membuktikan bahwa Realisasi Belanja Modal berpengaruh terhadap Pertumbuhan Ekonomi, yang berarti komponen Realisasi Belanja Modal yang terdiri dari Belanja Modal Tanah, Belanja Modal Peralatan dan Mesin, Belanja Modal Gedung dan Bangunan, Belanja Modal Jalan, Irigasi dan Jaringan, dan Belanja Modal Fisik lainnya sangat menunjang Pertumbuhan Ekonomi pada Provinsi di Indonesia. 
Penelitian ini telah dilakukan dengan optimal serta telah memenuhi prosedur penelitian, akan tetapi peneliti menyadari masih terdapat beberapa keterbatasan yang sulit dihindari dalam proses penelitian diantaranya: variabel independen yang digunakan peneliti untuk menganalisis Realisasi Belanja Modal hanya menggunakan dua variabel, yaitu Pendapatan Asli Daerah dan Dana Perimbangan, dan variabel independen yang digunakan peneliti untuk menganalisis Pertumbuhan Ekonomi hanya menggunakan satu variabel yaitu Realisasi Belanja Modal, tentunya masih terdapat kemungkinan terdapatnya beberapa variabel lain yang berpengaruh terhadap Realisasi Belanja Modal. Sampel yang dapat digunakan dalam penelitian ini dibatasi menjadi 32 yang memenuhi kriteria untuk dijadikan sampel, yang menyebabkan hasil penelitian hanya berlaku untuk provinsi yang dijadikan sampel, sedangkan provinsi di Indonesia sebanyak 33 Provinsi, sehingga generalisasi hasil temuan dan rekomendasi penelitian ini kurang dapat diberlakukan bagi seluruh provinsi di Indonesia. Rentang waktu yang digunakan dalam penelitian ini hanya diambil selama lima tahun, yaitu periode 2009 sampai dengan 2013 . Data yang digunakan dalam penelitian ini hanya menggunakan data Laporan Realisasi Anggaran (LRA) dan data Pertumbuhan Ekonomi Provinsi di Indonesia, bukan merupakan nilai akumulasi LRA dan Pertumbuhan Ekonomi Kabupaten/ Kota pada Provinsi di Indonesia.

\section{Daftar Referensi}

Abrar, Muhammad., (2010). Pengaruh Pendapatan Asli Daerah dan Belanja Modal Terhadap Pertumbuhan Ekonomi Provinsi Aceh. Jurnal Ekonomi dan Bisnis Vol. 9, No. 1, April 2010. pp. 79-88.

Adi, P. H., (2006). Hubungan Antara Pertumbuhan Ekonomi Daerah, Belanja Pembangunan dan Pendapatan Asli Daerah. Dalam Simposium Nasional Akuntansi IX Padang.
Anasmen., (2009). Pengaruh Belanja Modal Pemerintah pada Pertumbuhan Ekonomi di Provinsi Sumatera Barat: 2000-2006. Tesis. Universitas Indonesia. Depok. (dipublikasikan).

Arwati, D., \& Hadiati, N., (2013). Pengaruh Pertumbuhan Ekonomi, Pendapatan Asli Daerah dan Dana Alokasi Umum Terhadap Pengalokasian Anggaran Belanja Modal pada Pemerintah Daerah Kabupaten/Kota di Propinsi Jawa Barat.

Badan Pusat Statistik. (2008). Statistik Keuangan Pemerintah Propinsi Jawa Barat dan Kabupaten/Kota di Jawa Barat Tahun 2008.

Case, Karl E. \& Fair, Ray C., (2007). PrinsipPrinsip Ekonomi. Alih bahasa Y. Andri Zaimur, SE, Penerbit Erlangga, Jakarta.

Darwanto \& Yustikasari, Y., (2007). Pengaruh Pertumbuhan Ekonomi Pendapatan Asli Daerah dan Dana Alokasi Umum terhadap Pengalokasian Anggaran Belanja Modal. Simposium Nasional Akuntansi X. Makasar. Ghozali, Imam. (2006). Aplikasi Analisis Multivariate Dengan Program SPSS. Cetakan IV, Badan Penerbit Universitas Diponegoro, Semarang.

Gunantara., Putu Candra \& Dwirandra, A. A. N. B., (2014). Pengaruh Pendapatan Asli Daerah dan Dana Alokasi Umum pada Pertumbuhan Ekonomi dengan Belanja Modal sebagai Variabel Pemoderasi di Bali. E-Jurnal Akuntansi Universitas Udayana,7(3), pp.529-546, ISSN: 23028556.

Harianto, D., \& Adi, P. H., (2007). Hubungan Antara Dana Alokasi Umum, Belanja Modal, Pendapatan Asli Daerah dan Pendapatan Per Kapita. Simposium Nasional Akuntansi XMakasar, pp. 26-28.

Jaya, I., \& Dwirandra, A. A. N. B. , (2014). Pengaruh Pendapatan Asli Daerah Pada Belanja Modal Dengan Pertumbuhan Ekonomi Sebagai Variabel Pemoderasi. E-Jurnal Akuntansi Universitas Udayana, 
7(1), pp. 79-92.

Kuncoro, (2014). Otonomi Daerah Menuju Era Baru Pembangunan Daerah, Edisi 3, Penerbit Erlangga, Jakarta.

Laksono, B. B., \& Subowo, S., (2014). Pengaruh Pajak Daerah, Retribusi Daerah, Dau Dan Dak Terhadap Belanja Daerah. Accounting Analysis Journal, 3(4).

Lambut, A. K., \& Budiarso, N., (2013). Flypaper Effect Pada Dana Alokasi Umum (DAU) Dan Pendapatan Asli Daerah (PAD) Terhadap Belanja Daerah (BD) Pada Pemerintah Provinsi Sulawesi Utara. Accountability, 2(1), pp.11-19.

Lantang, D. D., Naukoko, A., \& Tumilaar, R., (2014). Analisis Dana Alokasi Umum (DAU), Pendapatan Asli Daerah Dan Belanja Daerah Di Kota Manado, pp.50.

Lapian, dkk., (2014). Pengaruh Belanja Daerah Dan Investasi Swasta Terhadap Pertumbuhan Ekonomi Di Kota Manado (Tahun 2002-2012), pp.122.

Mahmudi., (2010). Manajemen Keuangan Daerah, Penerbit Erlangga, Jakarta.

Mahmudi., (2010). Analisis Laporan Keuangan Pemerintah Daerah, Penerbit UPP STIM YKPN, Yogyakarta.

Mankiw, N. Gregory., (2007). Makroekonomi, Edisi 6, alih bahasa Fitria Liza dan Imam.

Mardiasmo. Otonomi dan Manajemen Keuangan Daerah Edisi III, Penerbit Andi. Yogyakarta.

Modebe, N.J., Regina G. Okafor, J.U.J Onwumere and Imo G. Ibe., (2012). Impact of Recurrent and Capital Expenditure on Nigeria's Economic Growth. European Journal of Business and Management, 4 (19), pp. 66-74.

Ndadari, Laras Wulan \& Adi, Priyo Hari., (2008). Perilaku Asimetris Pemerintah Daerah Terhadap Transfer Pemerintah Pusat. The 2nd National Conference UKWMS, Surabaya.

Nugraeni., (2011). Analisis Pengaruh Dana Alokasi Umum (DAU), Dana Alokasi
Khusus (DAK) Dan Pendapatan Asli Daerah (PAD) Terhadap Prediksi Belanja Daerah. Akmenika UPY, 8, pp. 96-117.

Oktora, Fahri Eka dan Winston Pontoh., 201. Analisis Hubungan Pendapatan Asli Daerah, Dana Alokasi Umum, Dan Dana Alokasi Khusus Atas Belanja Modal Pada Pemerintah Daerah Kabupaten Tolitoli Provinsi Sulawesi Tengah. Jurnal Accountability, 2(1), pp. 1-10.

Nugroho, Bhuono, Agung., (2005). Strategi Jitu Memilih metode Statistik Penelitian Dengan SPSS. Edisi I, Penerbit Andi, Yogyakarta.

Penthury, M.A., (2011). Flypaper Effects Anomaly Of West Papua Capital Public Expenditure. Economic Journal Of Emerging Markets, 3(3), pp. 289-297.

Peraturan Pemerintah Nomor 55 Tahun (2005) tentang Dana Perimbangan.

Peraturan Pemerintah Nomor 58 Tahun (2005) tentang Pengelolaan Keuangan Daerah.

Peraturan Pemerintah Nomor 71 tahun (2010) tentang Standar Akuntansi Pemerintahan.

Pujiati, Amin., (2008). Analisis Pertumbuhan Ekonomi di Karesidenan Semarang di Era Desentralisasi Fiskal. Jurnal Ekonomi Pembangunan. Kajian Ekonomi Negara Berkembang. pp. 61-70

Putro, Nugroho Suratno., (2010). Pengaruh Pertumbuhan Ekonomi, Pendapatan Asli Daerah dan Dana Alokasi Umum Terhadap Pengalokasian Anggaran Belanja Modal (Studi Kasus Pada Kabupaten/ Kota Di Provinsi Jawa Tengah). Skripsi Dipublikasikan, Jurusan Akuntansi Fakultas Ekonomi Universitas Diponegoro, Semarang.

Sholikhah, I., \& Wahyudin, A., (2014). Analisis Belanja Modal Pada Pemerintah Kabupaten/ Kota Di Jawa. Accounting Analysis Journal, 3(4).

Sugiyono., (2008). Metode Penelitian Administrasi, Penerbit CV. Alfabeta, Bandung. 
Supatman., (2010). Pengaruh Dana Alokasi Umum (DAU), Dana Alokasi Khusus (DAK) dan Pendapatan Asli Daerah (PAD) terhadap Pertumbuhan Ekonomi dengan Belanja Modal sebagai Variabel Intervening. Tesis. Universitas Padjadjaran Bandung.

Tambunan, Tulus., (2011). Perekonomian Indonesia, Penerbit Ghalia, Bogor.

Undang Undang Republik Indonesia Nomor 33 tahun 2004 tentang Perimbangan Keuangan Antara Pemerintah Pusat dan Pemerintah Daerah.
Ulum, I., (2005). Analisis Atas Dana Perimbangan Dan Pengaruhnya Terhadap Belanja Daerah Provinsi Di Indonesia. Jurnal Humanity, 1(1).

Wandira, A. G., (2013). Pengaruh PAD, DAU, DAK, dan DBH Terhadap Pengalokasian Belanja Modal. Accounting Analysis Journal, 2(1).

Wenas, C. L., Kumenaung, A., \& Rompas, W. Pengaruh Dana Alokasi Umum (Dau), Dan Pendapatan Asli Daerah (Pad) Terhadap Belanja Daerah Pemerintah Kota Manado Tahun (2002-2011), pp.25. 